\title{
Evaluation of KiSS1 as a Prognostic Biomarker in North Indian Breast Cancer Cases
}

\author{
Richa Singh ${ }^{1}$, Madan Lal Brahma Bhatt ${ }^{1 *}$,Saurabh Pratap Singh ${ }^{2}$, Vijay Kumar ${ }^{3}$, \\ Madhu Mati Goel ${ }^{4}$, Durga Prasad Mishra ${ }^{5}$, Rajendra Kumar ${ }^{1}$
}

\begin{abstract}
Background: Breast cancer is the commonest female cancer worldwide and its propensity to metastasize negatively impacts on therapeutic outcome. Several clinicopathological parameters with prognostic/predictive significance have been associated with metastatic suppressor expression levels. The role of metastatic suppressor gene (MSG) KiSS1 in breast cancer remains unclear. Our goal was to investigate the possible clinical significance of KiSS1 breast cancer. Materials and Methods: The study was conducted on 87 histologically proven cases of breast cancer and background normal tiisue. Quantitative reverse transcriptase polymerase chain reaction (qRT PCR) and immunohistochemistry (IHC) were used to investigate KiSS1 at gene and protein levels, respectively, for correlation with several patient characteristics including age, family history, hormonal receptor status, stage, tumor size, nodal involvement and metastatic manifestation and finally with median overall survival (OS). Results: Our study revealed (i) KiSS1 levels were generally elevated in breast cancer vs normal tissue $(P<0.05)$. (ii) however, a statistically significant lower expression of KiSS1 was observed in metastatic vs non metastatic cases $(P=0.04)$. (iii) KiSS1 levels strongly correlated with $T, N, M$ category, histological grade and advanced stage ( $\mathbf{p}<\mathbf{0 . 0 0 1}$ ) but not other studied parameters. (iv) Lastly, a significant correlation between expression of KiSS1 and median OS was found $(P=0.04)$. Conclusions: Conclusively, less elevated KiSS1 expression is a negative prognostic factor for OS, advancing tumor stage, axillary lymph node status, metastatic propensity and advancing grade of the breast cancer patient. Patients with negative KiSS1 expression may require a more intensive therapeutic strategy.
\end{abstract}

Keywords: Breast cancer - prognosis - KiSS1 - North India - metastasis

Asian Pac J Cancer Prev, 17 (4), 1789-1795

\section{Introduction}

Breast cancer, a familial, heterogeneous disease, is the second most common cancer among women in the world and, by far 232,340 new cases of invasive breast cancer and 39,620 breast cancer deaths have affected US women in 2013 (DeSantis et al., 2013). In India, breast cancer ranks first leaving cervical cancer behind in terms of annual incidence (Asthana et al., 2014). Metastasis contributes to treatment failure and increased morbidity and mortality of breast cancer making it a clinically and socially important issue.

The purpose of the present study was to determine the mRNA and protein expression of KiSS1 in breast cancer and its significance as a prognosticator in breast cancer tissues since data in literature is inconclusive. The preliminary evidence of KiSS 1 expression being elevated in patients with breast tumors was shown in an investigation by Martin and coworkers (Martin et al., 2005). They demonstrated that KiSS1 mRNA and protein expression were increased with increase in tumor grade and in metastatic patients vs control population and that this was associated with poor patient prognosis. Contradictory to Martin's study other reports indicate that KiSS1 mRNA and protein expression were also found to be significantly higher in primary breast cancer compared with breast tumors that metastasized to the brain (Ulasov et al., 2012; Stark et al., 2005). This suggests that a loss of KiSS1 may contribute to the formation of distant metastases, since there was a down-regulation of KiSS1 expression in the metastases compared to primary tumors (Ulasov et al., 2012) Thus, these studies support the antimetastatic role of KiSS1(Ulasov et al., 2012). The reason for these conflicting results could be a difference in the method of analysis of patient samples, patient inclusion and exclusion criteria such as whether the patients had

${ }^{I}$ Department of Radiotherapy, ${ }^{3}$ Department of Surgical Oncology, ${ }^{4}$ Department of Pathology, King George's Medical University, ${ }^{2}$ Department of Hematology, Sanjay Gandhi Post Graduate Institute of Medical Sciences, ${ }^{5}$ Endocrinology Division, Central Drug Research Institute (CSIR), Lucknow, India*For correspondence: drmlbhatt@yahoo.com 
received chemotherapy, the age of the women (pre- versus post-menopausal) and the different gene pool of the patient subset (Donna et al., 2013).

Metastasis suppressors are a family of molecules that are defined functionally by their ability to suppress metastasis without blocking the growth of orthotopic, primary tumor when re-expressed (Christopher et al., 2014). Originally identified in 1996 in human melanoma and breast carcinoma cells, (Lee et al., 1996), KiSS1 structurally comprises of a precursor protein that is processed into several related peptides, generically named as kisspeptins (Messager et al., 2005;Makri et al., 2008) and the major product kisspeptin-54 or metastin is a 54 amino acid long peptide. At the C-terminal region, lies 14,11 and 10 amino acid long peptide lengths sharing a common 10 amino acid $\mathrm{C}$ terminal region (Kotani et al., 2001; Ohtaki et al., 2001). The KiSS1 gene is located on chromosome 1 near q32.1 with regulatory elements localized in chromosome 6 at 6q16.3-q23 (Makri et al., 2008) and has four exons of which the 5' and 3 ' exons are only partly translated (Messager et al., 2005). Off late KiSS 1 has been shown to be epigenetically silenced by hypermethylation in bladder cancer (Cebrian et al., 2011) and colorectal cancer (Moya et al., 2013). Data amassed from the literature support the hypothesis that loss of KiSS 1 expression has been associated with the progression and metastasis of various tumors, including esophageal, brain, ovarian and melanoma (Li et al., 2012; Sun et al., 2013; Okugawa et al., 2013). Expression of KiSS1 like other MSGs is commonly reduced or completely absent in a variety of cancers via an unknown mechanism (Mitchell et al., 2007). In the present study, expression levels of KiSS1 molecules were studied and a correlation was established with the clinicopathological parameters.

Several clinicopathological parameters have been implicated in prognosis, recurrence and survival of breast cancer. Tumor size, axillary lymph node involvement and extent of metastasis are important prognostic determinants for breast cancer patients (Gur et al., 2010). Estrogen receptor (ER) is long known as a prognostic and a predictive factor for breast cancer (Bevilacqua et al., 2007). Progesterone receptor (PR) status is also correlated with axillary lymph node involvement and hormone receptor status remains the most significant predictive and prognostic biomarker (Mickey et al., 1989; Harvey et al., 1999). Her2 neu also serves as prognosticator according to earlier reports (Mansel et al., 2006). Late onset of menarche, ever oral contraceptive (OCP) usage, breast feeding for 1-2 years, and age of first childbirth between 20-30 years were thought to be protective factors (Das et al., 2012). These data together indicate that many clinicopathological parameters may play a key role in breast cancer prognosis and prediction of its risk.

The current investigation aims to establish a correlation, if any of the transcriptomic and protein expression of KiSS1 gene with the clinicopathological parameters and prognosis of breast cancer in North Indian patients.

\section{Materials and Methods}

The study group comprised of 87 histologically proven cases of breast cancer and corresponding normal breast tissue from the same breast resection specimen. Eighty seven cases included 29 distant metastasis and 58 non metastatic patients.

The samples were collected from Department of Surgical Oncology, King George's Medical University, Lucknow between November 2011 and December 2012. Breast cancer tissue from tumor mass was obtained for the study. Adjacent normal tissue from the mastectomy specimen served as the control tissue. None of the patients received preoperative chemotherapy or radiation therapy. The Institutional Ethics Committee at King George's Medical University, Lucknow approved the study protocol. Written voluntary informed consent was obtained from all patients before recruitment. KiSS1 expression at gene and protein level was studied by qRT PCR and immunohistochemistry, respectively. The tissue biopsies were collected in 10x buffered formalin at room temperature for immunohistochemical diagnosis and in RNA later at $-80^{\circ} \mathrm{C}$ until further use for qRT PCR.

\section{Quantitative Real Time PCR:}

Total mRNA was isolated following single step mRNA isolation method using RNA isolation kit (Invitrogen, USA). Total mRNA ( $2 \mu \mathrm{g})$ was reverse transcribed to cDNA using RT-PCR kit (Applied Biosystems, USA) following manufacturer's instructions. Real time analysis for KiSS1 and normalizing gene GAPDH was performed using SYBR GREEN MASTER mix as per the manufacturer's instructions (Applied Biosytems, USA). Analysis was done on Light-cycler 480 (Roche, USA) and fold changes in gene expression were calculated using 2- $\triangle \triangle C T$ method. The qRTPCR primer sequences were 5'-ACCTGCCTCTTCTCACCAAG-3' and 5'-TAGCAGCTGGCTTCCTCTC-3' for KiSS1; and 5'-AAATCAAGTGGGGCGATGCTG-3' and 5'-GCAGAGATGATGACCCTTTTG-3' for GAPDH.

\section{Immunohistochemistry}

Formalin-fixed, paraffin-embedded tissue sections were cut into $4 \mu \mathrm{m}$-thick sequential sections. After deparaffinization and rehydration, sections were boiled in citrate buffer $(0.01 \mathrm{M}, \mathrm{pH} 6.0)$ for antigen retrieval. Sections were then incubated with $3 \% \mathrm{H} 2 \mathrm{O} 2$ and $5 \%$ serum to block endogenous peroxidase activity and non-specific binding. For KiSS1 protein, sections were incubated with rabbit anti-human KiSS1 monoclonal antibody (sc-101246). The sections were then incubated with biotinylated secondary antibodies and visualized by DAB. Counterstaining was carried out with hematoxylin. The sections were dehydrated in alcohol and mounted with DPX. For the negative controls, PBS replaced the primary antibody.

\section{Immunohistochemical Scoring for KiSS1:}

IHC evaluation was performed under a microscope by an observer unbiased without the knowledge of clinical outcome. Cyto-membranous staining was considered positive for KiSS1 expression. The patterns of staining were applied into scales on $\%$ of cells with positive immunostaining as $0=$ complete absence or negative 
Table 1. Correlation of KiSS1 Gene Expression with Patient Clinical \& Histopathological Characteristics of Breast Cancer Patients

\begin{tabular}{|c|c|c|c|}
\hline Variables & $\begin{array}{c}\text { KiSS1 high } \\
(>4) \\
(\mathrm{n}=48) \\
(64.0 \%) \\
\end{array}$ & $\begin{array}{c}\begin{array}{c}\text { KiSS1 low } \\
(\leq 4)\end{array} \\
(n=27) \\
(36.0 \%) \\
\end{array}$ & $P$ value \\
\hline Age & & & 0.169 \\
\hline$\leq 45$ & $26(54.2 \%)$ & $19(70.4 \%)$ & \\
\hline$>45$ & $22(45.8 \%)$ & $08(29.6 \%)$ & \\
\hline Parity & & & 0.741 \\
\hline$\leq 2$ & $32(66.7 \%)$ & $19(70.4 \%)$ & \\
\hline$>2$ & $16(33.3 \%)$ & $08(29.6 \%)$ & \\
\hline Oral contraceptives & & & 0.968 \\
\hline No & $30(62.5 \%)$ & $17(63.0 \%)$ & \\
\hline Yes & $18(37.5 \%)$ & $10(37.0 \%)$ & \\
\hline Family history & & & 0.627 \\
\hline No & $33(68.8 \%)$ & $20(74.1 \%)$ & \\
\hline Yes & $15(31.2 \%)$ & $07(25.9 \%)$ & \\
\hline Menopause & & & 0.39 \\
\hline No & $14(29.2 \%)$ & $05(18.5 \%)$ & \\
\hline Yes & $34(70.8 \%)$ & $22(81.5 \%)$ & \\
\hline Nodes & & & $<0.001$ \\
\hline$\leq 2$ & $40(83.3 \%)$ & $11(40.7 \%)$ & \\
\hline$>2$ & $08(16.7 \%)$ & $16(59.3 \%)$ & \\
\hline Node & & & $<0.001$ \\
\hline No & $06(12.5 \%)$ & $04(23.8 \%)$ & \\
\hline N1 & $19(39.6 \%)$ & $00(0.0 \%)$ & \\
\hline $\mathrm{N} 2$ & $15(31.3 \%)$ & $07(25.9 \%)$ & \\
\hline N3 & $08(16.7 \%)$ & $16(59.3 \%)$ & \\
\hline Tumor & & & 0.011 \\
\hline$\leq 3$ & $41(85.4 \%)$ & $16(59.3 \%)$ & \\
\hline$>3$ & $07(14.6 \%)$ & $11(40.7 \%)$ & \\
\hline Tumor & & & 0.003 \\
\hline $\mathrm{T} 2$ & $07(14.6 \%)$ & $04(14.8 \%)$ & \\
\hline $\mathrm{T} 3$ & $12(25.0 \%)$ & $11(40.7 \%)$ & \\
\hline $\mathrm{T} 4$ & $07(14.6 \%)$ & $11(40.7 \%)$ & \\
\hline Metastasis & & & $<0.001$ \\
\hline M0 & $40(83.3 \%)$ & $11(40.7 \%)$ & \\
\hline M1 & $8(10.67 \%)$ & $16(59.3 \%)$ & \\
\hline ER & & & 0.67 \\
\hline -ve & $26(54.2 \%)$ & $16(59.3 \%)$ & \\
\hline$+\mathrm{ve}$ & $22(45.8 \%)$ & $11(40.7 \%)$ & \\
\hline PR & & & 0.95 \\
\hline -ve & $21(43.8 \%)$ & $12(44.4 \%)$ & \\
\hline$+\mathrm{ve}$ & $27(56.2 \%)$ & $15(55.6 \%)$ & \\
\hline Her2 neu & & & 0.15 \\
\hline -ve & $12(25.0 \%)$ & $11(40.7 \%)$ & \\
\hline$+\mathrm{ve}$ & $36(75.0 \%)$ & $16(59.3 \%)$ & \\
\hline Histological grade & & & 0.049 \\
\hline Well differentiated & $16(33.3 \%)$ & $06(22.2 \%)$ & \\
\hline $\begin{array}{r}\text { Moderately } \\
\text { differentiated }\end{array}$ & $27(56.3 \%)$ & $12(44.4 \%)$ & \\
\hline
\end{tabular}

Table 1 (continued). Correlation of KiSS1 Gene Expression with Patient Clinical \& Histopathological Characteristics of Breast Cancer Patients

\begin{tabular}{lccc}
\hline \multirow{2}{*}{ Variables } & $\begin{array}{c}\text { KiSS1 high } \\
(>4)\end{array}$ & $\begin{array}{c}\text { KiSS1 low } \\
(\leq 4)\end{array}$ & P value \\
\cline { 2 - 3 } & $(\mathrm{n}=42)$ & $(\mathrm{n}=33)$ & \\
& $(56.0 \%)$ & $(44.0 \%)$ & \\
Histological type & & & 0.324 \\
Lobular invasive & $17(35.4 \%)$ & $13(48.1 \%)$ & \\
Ductal invasive & $13(27.1 \%)$ & $06(22.2 \%)$ & \\
Medullary & $10(20.8 \%)$ & $07(25.9 \%)$ & \\
Others & $08(16.7 \%)$ & $01(3.8 \%)$ & \\
Stage & & & 0.002 \\
I & $30(62.5 \%)$ & $05(19.6 \%)$ & \\
II & $07(14.5 \%)$ & $11(40.7 \%)$ & \\
III & $08(16.7 \%)$ & $07(25.9 \%)$ & \\
IV & $03(6.3 \%)$ & $04(14.8 \%)$ & \\
\hline
\end{tabular}

staining, $1=$ less than $10 \%$ positive cells, $2=$ greater than $10 \%$ and less than $50 \%$ cells and $3=$ more than $50 \%$ cells positive. In general staining in less than $10 \%$ was considered as negative staining and more than $10 \%$ was considered positive for KiSS1.

\section{Statistical analysis}

Continuous data were summarized as mean $\pm \mathrm{SE}$, while discrete (categorical) in \%. Qualitative variables were expressed as numbers and percentages. Comparisons were made between categorical groups by chi-square $(\chi 2)$ test. Comparisons were made between two independent groups by independent Student's t-test. A two tailed $\mathrm{p}<0.05$ was considered statistically significant. Kaplan Meier survival curve was made and survival time was compared using Log rank test. All analysis was performed on SPSS (Windows version 21.0) software.

\section{Results}

The study included 87 histologically proven cases of breast cancer and similar number of age matched control tissues. The median age of the patients was 49 years (range, 18-70 years).

Quantitative mRNA expression was analysed using RT-PCR in 87 breast cancer tumors and same number of controls. The mean fold expression of gene indicated that it was overexpressed $8.68 \pm 2.3$ fold in breast cancer as compared to controls, whilst in non metastatic cases it was overexpressed $3.2 \pm 1.87$ fold as compared to metastatic cases. Moreover, KiSS1 expression was higher in $55.2 \%(48 / 87)$ patients who exhibited high (>4) KiSS1 expression and 31.0\% (27/87) had low ( $\leq 4)$ breast cancer cases, and undetectable in $13.8 \%(12 / 87)$ breast cancer cases. The relationship between KiSS1 mRNA and clinicopathological features of breast cancer is summarized (Table 1).

Immunohistochemistry: Since, KiSS1 gene was detectable in $86.2 \%$ cases in mRNA expression analysis; hence we proceeded with IHC for 75 cases and discarded the rest $13.8 \%$. Cyto membranous expression was 
Table 2. Correlation of KiSS1 Protein Expression with Patient Clinical \& Histopathological Characteristics of Breast Cancer Patients

\begin{tabular}{|c|c|c|c|}
\hline \multirow[b]{2}{*}{ Variables } & KiSS1 high $(>4)$ & KiSS1 low $(\leq 4)$ & \multirow[b]{2}{*}{ P value } \\
\hline & $(\mathrm{n}=42)(56.0 \%)$ & $(n=33)(44.0 \%)$ & \\
\hline \multicolumn{3}{|l|}{ Age } & 0.128 \\
\hline$\leq 45$ & $22(52.3 \%)$ & $23(69.7 \%)$ & \\
\hline$>45$ & $20(47.7 \%)$ & $10(30.3 \%)$ & \\
\hline \multicolumn{3}{|l|}{ Parity } & 0.78 \\
\hline$\leq 2$ & $28(66.7 \%)$ & $23(69.6 \%)$ & \\
\hline$>2$ & $14(33.3 \%)$ & $10(30.4 \%)$ & \\
\hline \multicolumn{3}{|c|}{ Oral contraceptives } & 0.743 \\
\hline No & $27(64.2 \%)$ & $20(60.6 \%)$ & \\
\hline Yes & $15(35.7 \%)$ & $13(39.3 \%)$ & \\
\hline \multicolumn{3}{|l|}{$\begin{array}{l}\text { Family } \\
\text { history }\end{array}$} & 0.728 \\
\hline No & $29(69.1 \%)$ & $24(72.7 \%)$ & \\
\hline Yes & $13(30.9 \%)$ & $09(27.2 \%)$ & \\
\hline \multicolumn{3}{|l|}{ Menopause } & 0.467 \\
\hline No & $12(28.5 \%)$ & $07(21.2 \%)$ & \\
\hline Yes & $30(71.4 \%)$ & $26(78.7 \%)$ & \\
\hline \multicolumn{3}{|l|}{ Node } & 0.001 \\
\hline$\leq 2$ & $35(83.3 \%)$ & $16(48.4 \%)$ & \\
\hline$>2$ & $07(16.7 \%)$ & $17(51.5 \%)$ & \\
\hline \multicolumn{3}{|l|}{ Node } & 0.001 \\
\hline No & $05(11.9 \%)$ & $05(15.2 \%)$ & \\
\hline N1 & $17(40.4 \%)$ & $02(6.0 \%)$ & \\
\hline $\mathrm{N} 2$ & $13(30.9 \%)$ & $09(27.2 \%)$ & \\
\hline N3 & $07(16.8 \%)$ & $17(51.5 \%)$ & \\
\hline \multicolumn{3}{|l|}{ Tumor } & 0.026 \\
\hline$\leq 3$ & $36(85.7 \%)$ & $21(63.6 \%)$ & \\
\hline$>3$ & $06(14.3 \%)$ & $12(36.4 \%)$ & \\
\hline \multicolumn{3}{|l|}{ Tumor } & 0.025 \\
\hline $\mathrm{T} 2$ & $06(14.3 \%)$ & $05(15.2 \%)$ & \\
\hline $\mathrm{T} 3$ & $11(26.2 \%)$ & $12(36.3 \%)$ & \\
\hline $\mathrm{T} 4$ & $06(14.3 \%)$ & $12(36.3 \%)$ & \\
\hline \multicolumn{3}{|l|}{ Metastasis } & 0.001 \\
\hline M0 & $35(83.3 \%)$ & $16(48.5 \%)$ & \\
\hline M1 & $07(10.67 \%)$ & $17(51.5 \%)$ & \\
\hline \multicolumn{3}{|l|}{ ER } & 0.807 \\
\hline -ve & $23(54.7 \%)$ & $19(57.6 \%)$ & \\
\hline$+\mathrm{ve}$ & $19(45.3 \%)$ & $14(42.4 \%)$ & \\
\hline \multicolumn{3}{|l|}{ PR } & 0.476 \\
\hline -ve & $20(47.6 \%)$ & $13(39.4 \%)$ & \\
\hline$+\mathrm{ve}$ & $22(52.4 \%)$ & $20(60.6 \%)$ & \\
\hline \multicolumn{3}{|l|}{ Her2 neu } & 0.146 \\
\hline -ve & $10(23.8 \%)$ & $13(39.4 \%)$ & \\
\hline$+\mathrm{ve}$ & $32(76.2 \%)$ & $20(60.6 \%)$ & \\
\hline
\end{tabular}

Table 2 (continued). Correlation of KiSS1 Protein Expression with Patient Clinical \& Histopathological Characteristics of Breast Cancer Patients

\begin{tabular}{lccc}
\hline Variables & KiSS1 high $(>4)$ & KiSS1 low $(\leq 4)$ & \multirow{2}{*}{ P value } \\
\cline { 2 - 3 } & $(\mathrm{n}=42)(56.0 \%)$ & $(\mathrm{n}=33)(44.0 \%)$ & \\
\hline Histologi- & & & 0.013 \\
cal grade & & & \\
Well diff & $15(35.7 \%)$ & $07(21.2 \%)$ & \\
Mod diff & $24(57.1 \%)$ & $15(45.4 \%)$ & \\
Poor diff & $03(7.0 \%)$ & $11(33.4 \%)$ & \\
Histologi- & & & \\
cal type & & & \\
Lobular & $15(35.7 \%)$ & $15(45.4 \%)$ & \\
invasive & & & \\
Ductal & $11(26.2 \%)$ & $08(24.2 \%)$ & \\
invasive & & & \\
Medul- & $09(21.4 \%)$ & $08(24.2 \%)$ & \\
lary & $07(16.7 \%)$ & $02(6.2 \%)$ & \\
Others & & & \\
Stage & $26(61.9 \%)$ & $09(27.2 \%)$ & \\
I & $06(14.3 \%)$ & $12(36.4 \%)$ & \\
II & $07(16.7 \%)$ & $08(24.2 \%)$ & \\
III & $03(7.1 \%)$ & $04(12.2 \%)$ & \\
IV & & & \\
\hline
\end{tabular}

Table 3. Association of Survival of Patient with KiSS1 Gene Expression

\begin{tabular}{lcc}
\hline \multicolumn{1}{c}{ Variables } & $\begin{array}{c}\text { Median survival in } \\
\text { months }\end{array}$ & P value \\
\hline KiSS 1 high expression & 20.42 & 0.045 \\
KiSS 1 low expression & 16.95 & \\
\hline
\end{tabular}

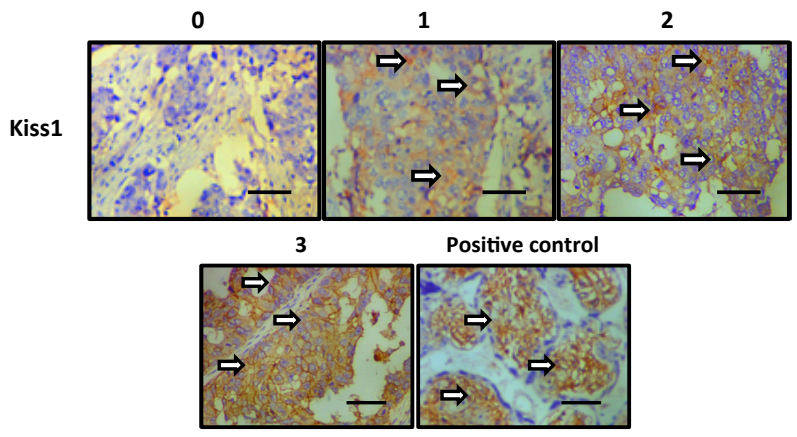

Figure 1. Immunohistochemistry images of breast cancer. Representative figures showing cytoplasmic+ membranous staining for KiSS1. Representative staining results of KiSS1 expressed are shown at 20× original magnification. Sections of formalin-fixed paraffin-embedded specimens were stained for KiSS1 antibodies. Positive staining for the KiSS1 antibody is shown, illustrating 0 to $3+$ staining scale. Placenta of the second trimester rich in decidual cells was used as positive control. Arrows point to the stained cells

analysed using IHC in 75 breast cancer tumors and similar number of age matched controls. KiSS1 expression was 1 positive in $17.3 \%(13 / 75)$ breast cancer cases, 2 positive in $8 \%(06 / 75)$ breast cases, 3 positive in $30.6 \%$ $(23 / 75)$ cases and negative in $30.6 \%(33 / 75)$ breast cases (Figure 1). The relationship between KiSS1 mRNA 


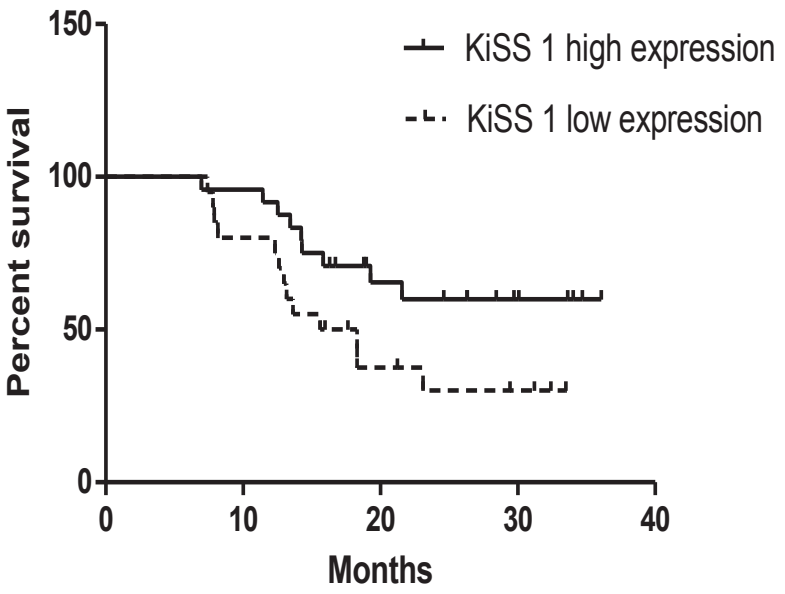

Figure 2. Kaplan-Meier Survival Curve after 3 Years

of Follow-up. Significant association of KiSS 1 level $(\mathrm{p}=0.04)$ in negative KiSS1 group versus positive KiSS1 group had been observed

and clinicopathological features of breast cancer is summarized (Table 2).

Clinico pathological characteristics with reference to KiSS 1 genes: The present study showed that downregulation of KiSS1 at the gene and protein level is significantly correlated with advanced T,N,M categories and higher grade. No significant correlation was observed between KiSS1 expression and age, ER, PR, Her2neu and menopausal status (Tables $1 \& 2$ ).

KiSS 1 expression in different stages and histological grade: The mRNA analysis showed that KiSS1 expression was low in advanced vs early stage $(2.25 \pm 0.75, \mathrm{p}<0.05)$. Similar results were found in protein analysis wherein KiSS 1 expression levels were lower in advanced as compared to early stage of the disease $(11.68 \pm 3.23$, $\mathrm{p}<0.05)$.

We were unable to identify any significant correlation of KiSS1 transcript level between grade 1 (well differentiated) and grade 2 (moderately differentiated) and also between grade 3 (poorly differentiated) and grade 2 breast cancer tissues. The mRNA analysis showed that KiSS1 expression was low in poor vs well differentiated tissues $(2.50 \pm 1.25, \mathrm{p}<0.05)$. Protein analysis also corroborated similar findings wherein KiSS1 expression levels were lower in poorly differentiated tumors as compared to well differentiated tumors $(10.73 \pm 2.63$, $\mathrm{p}<0.05$ ) (Tables $1 \& 2$ ).

KiSS1 expression and its correlation with median overall survival: According to the Log rank test median OS, 20.42 months was the median survival for KiSS1 high/ positive patients as compared to 16.9 months for KiSS1 low/negative patients. This difference was statistically significant $(\mathrm{p}=0.045)$ (Figure $2 \&$ Table 3$)$.

\section{Discussion}

KiSS1 has been evaluated in a number of cancers like colon, gastric, prostate, lung (Dhar et al., 2004; Schumacher et al., 2007; Sasaki et al., 2008; Li et al., 2012; Sun et al, 2013), not much literature is available on Indian population. The clinicopathological parameters have not been studied in detail in a single population in context to associating with metastatic markers and metastatic propensity. In this cohort study, individuals from North Indian patients with breast cancer were considered.

We found low expression of KiSS1 in non cancerous as compared to breast cancer tissue $(\mathrm{p}<0.05)$. Yet another study demonstrated that there was a significant increase in KiSS1 expression levels in cancerous tissues compared with benign and normal tissue in ovarian cancer using immunohistochemical staining (Gao et al., 2007). Kostakis et al. (2013) however reported contradictory findings in normal vs malignant colonic mucosa.

KiSS 1 expression was higher in non metastatic breast tissue vs metastatic breast tissue ( $<<0.05)$. Dhar et al., (2004) also found that gastric cancers with low KiSS1 had distant metastasis. Schmid et al., (2007) studied the expression of KiSS1 gene in HCC and found lower levels in non cancerous vs cancer mucosa. Dissimilar to our findings, Karapanagiotou et al., (2011) found that KiSS1 is not involved in metastatic potential of non-small cell lung cancer.

KiSS 1 levels were attenuated in advanced T category vs lower $\mathrm{T}$ category in our study $(\mathrm{p}<0.05)$. The expression level of Kiss-1 decreased as TNM stage progressed in colorectal cancer (Ke et al., 2014). Moreover, low levels of KiSS 1expression are associated with increased histopathological stage in bladder cancer (Sanchezet al., 2013). Yao et al., (2007) also demonstrated reduced KiSS1expression in T3/T4 gastric tumours with lymph node involvement and distant metastases compared with tumours at earlier stages. In sharp contrast to our results were the findings of Martin et al., (2005) who showed that KiSS1increased in relation to tumour grade and increased TMN status in breast cancer.

Node negative vs node positive tumors revealed statistical downregulation of KiSS1 $(\mathrm{p}<0.05)$ Consistent with our study, loss of KiSS1 expression was found to be a significant predictor and a potential biomarker of lymph node metastasis in esophageal squamous cell carcinoma (Tachibana et al., 1999).

We also found lower KiSS1 expression in poorly differentiated in comparison to well differentiated ones $(p<0.05)$. Moreover, low levels of KiSS1expression were also demonstrated to be associated with increased histopathological stage, poor tumour cell differentiation in bladder cancer (Sanchez-Carbayo et al., 2013). The down regulation of KiSS1has been shown to be inversely associated with clinical stage and tumour grade in prostate carcinoma (Wang et al., 2005). Our results are in contrast to Martin's findings where the expression of KiSS1increased in relation to tumour grade (Martin et al., 2005).

Median OS was better in KiSS1 high group (20.42 months) as compared to KiSS1 low group (16.95 months). Reduced KiSS1 expression was shown to be a strong prognostic marker in determining median survival in urinary bladder cancer and gastric cancer patients (Dhar et al., 2004; Masui et al., 2004) which were in agreement with our findings. Differing from our reports, the findings by Kostadima et al., 2007 revealed no significant difference between kiSS1 negative and positive 
groups $(\log$-rank $\mathrm{p}=0.55$ and $\mathrm{p}=0.54)$ in overall survival and disease free survival respectively hence indicating negative correlation of KiSS1 transcriptional status with prognostic significance.

In conclusion, these results provide clinical evidence to support that KiSS1 is a breast carcinoma MSG. Our results also suggest that measuring KiSS1 expression will help to identify those breast cancer patients with metastatic propensity and hence guide clinicians to risk stratify their breast cancer patients and need for early intervention. Further functional studies are needed to elucidate the mechanism of metastasis suppression by KiSS1 and to confirm its metastasis suppression function in other tumor types and models. In addition, the clinical significance of KiSS 1 mRNA expression in breast cancer warrants study of KiSS1 protein levels in a large cohort of patients.

\section{Acknowledgements}

The authors wish to thank all those who have cooperated in the study. Present work was funded by the Indian Center for Medical Research (ICMR), New Delhi, India for providing Senior Research fellowship to first author Richa Singh (3/2/2/119/2012/NCD-III).

\section{References}

Asthana S, Chauhan S, Labani S (2014). Breast and cervical cancer risk in India: an update. Indian J Public Health, $\mathbf{5 8}, 5-10$

Bevilacqua JL, Kattan MW, Fey JV, et al (2007). Doctor, what are my chances of having a positive sentinel node? A validated nomogram for risk estimation. J Clin Oncol, 25, 3670-79.

Cebrian V, Fierro M, Orenes-Piñero E, et al (2011). KiSS1 methylation and expression as tumor stratification biomarkers and clinical outcome prognosticators for bladder cancer patients. Am J Pathol, 179, 540-6.

Christopher R. Bohl, Sitaram Harihar, Warren L. Denning, et al (2014). Metastasis suppressors in breast cancers: mechanistic insights and clinical potential. J Mol Med (Berl), 92, 3-30.

Das S, Sen S, Mukherjee A, Chakraborty D, et al (2012). Risk factors of breast cancer among women in eastern India: A tertiary hospital based case control study. Asian Pac J Cancer Prev, 13, 4979-81.

DeSantis C, Ma J, Bryan L, et al (2013). Breast cancer statistics, 2013. CA Cancer J Clin, 64, 52-62.

Dhar DK, Naora H, Kubota H, et al (2004). Downregulation of KiSS-1 expression is responsible for tumor invasion and worse prognosis in gastric carcinoma. Int J Cancer, 111, 868-72.

Donna Cvetkovic, Andy V. Babwah, Moshmi Bhattacharya (2013). Kisspeptin/KiSS1R system in breast cancer. $J$ Cancer, 8, 653-61.

Gao GL,Liu LD,Zou XS, Chen WX(2007). Expression of KiSS-1, matrix metalloproteinase-9, nuclear factor-kappaBp65 in ovarian tumour. Zhonghua Fu Chan Ke Za Zhi, 42, 34-38

Gur AS, Unal B, Ozbek U, et al (2010). Validation of breast cancer nomograms for predicting the non-sentinel lymph node metastases after a positive sentinel lymph node biopsy in a multi-center study. Eur J Surg Oncol, 36, 30-35.

Harvey JM, Clark, GM, Osborne, CK, et al, (1999). Estrogen receptor status by immunohistochemistry is superior to the ligand-binding assay for predicting response to adjuvant endocrine therapy in breast cancer. J Clin Oncol, 17, 1474-
81.

$\mathrm{Ke} \mathrm{Ji,} \mathrm{Lin} \mathrm{Ye,} \mathrm{Fiona} \mathrm{Ruge} \mathrm{et} \mathrm{al} \mathrm{(2014).} \mathrm{Implication} \mathrm{of} \mathrm{metastasis}$ suppressor gene, Kiss-1 and its receptor Kiss-1R in colorectal cancer, BMC Cancer, 14,723.

Karapanagiotou EM, Dilana KD, Gkiozos I, et al (2011). Metastin is not involved in metastatic potential of non-small cell lung cancer. Med Oncol, 28, 559-64.

Kostadima L, Pentheroudakis G Pavlidis N (2007). The missing kiss of life: transcriptional activity of the metastasis suppressor gene KiSS1 in early breast cancer. Anticancer Res, 27, 2499-504.

Kostakis ID, Agrogiannis G, Vaiopoulos AG, et al (2013). KiSS1 expression in colorectal cancer. APMIS, 121, 1004-10.

Kotani M, Detheux M, Vandenbogaerde A, et al (2001). The metastasis suppressor gene KiSS-1 encodes kisspeptins, the natural ligands of the orphan $\mathrm{G}$ protein-coupled receptor GPR54. J Biol Chem, 276, 34631-36.

Lee JH, Miele ME, Hicks D, et al, (1996). KiSS-1, a novel human malignant melanoma metastasis-suppressor gene. $J$ Natl Cancer Inst, 88, 1731-7.

Li N, Wang HX, Zhang J, et al (2012). KISS-1 inhibits the proliferation and invasion of gastric carcinoma cells. World J Gastroenterol, 18, 1827-33.

Makri A, Pissimissis N, Lembessis P, et al (2008). The kisspeptin (KiSS-1)/GPR54 system in cancer biology. Cancer Treat Rev, 34, 682-92.

Mansel RE, Fallowfield, L, Kissin, M, et al (2006). Randomized multicenter trial of sentinel node biopsy versus standard axillary treatment in operable breast cancer: The ALMANAC trial. J Natl Cancer Inst, 98, 599-609.

Martin TA, Watkins G, Jiang WG (2005). KiSS-1 expression in human breast cancer. Clin Exp Metastasis, 22, 503-11.

Masui T, Doi R, Mori T, et al (2004). Metastin and its variant forms suppress migration of pancreatic cancer cells. Biochem Biophys Res Commun, 315, 85-92.

Messager S- (2008). Kisspeptin and its receptor: new gatekeepers of puberty. J Neuroendocrinol, 17, 687-8.

Mickey RM and Greenland S (1989). The impact of confounder selection criteria on effect estimation. Am J Epidemiol. 129, 129-37.

Mitchell DC, Stafford LJ, Li D, et al (2007). Transcriptional regulation of KiSS-1 gene expression in metastatic melanoma by specificity protein- 1 and its coactivator DRIP130. Oncogene, 26, 1739-47.

Moya P, Esteban S, Fernandez-Suarez A, et al (2013). KiSS-1 methylation and protein expression patterns contribute to diagnostic and prognostic assessments in tissue specimens for colorectal cancer. Tumour Biol, 34, 471-9.

Ohtaki T, Shintani Y,Honda S, et al (2001). Metastasis suppressor gene KiSS-1 encodes peptide ligand of a G-protein-coupled receptor. Nature, 31, 613-7.

Okugawa Y, Inoue Y, Tanaka K, et al (2013). Loss of the metastasis suppressor gene KiSS1 is associated with lymph node metastasis and poor prognosis in human colorectal cancer. Oncol Rep, 3, 1449-54.

Sanchez-Carbayo M, Capodieci P and Cordon-Cardo C (2003). Tumor suppressor role of KiSS-1 in bladder cancer: loss of KiSS- 1 expression is associated with bladder cancer progression and clinical outcome. Am J Pathol, 162, 609-17.

Sasaki H, Miura K, Horii A, et al (2008). Orthotopic implantation mouse model and cDNA microarray analysis indicates several genes potentially involved in lymph node metastasis of colorectal cancer. Cancer Sci, 99, 711-719.

Schumacher P, Dineen S, Barnett C Jr, et al (2007). The metastatic lymph node ratio predicts survival in colon cancer. Am J Surg, 194, 827-31.

Schmid K, Wang X, Haitel A, et al (2007). KiSS-1 overexpression 
as an independent prognostic marker in hepatocellular carcinoma: an immunohistochemical study. Virchows Arch, 450, $143-9$.

Stark AM, Tongers K, Maass N, et al (2005). Reduced metastasissuppressor gene mRNA-expression in breast cancer brain metastases. J Cancer Res Clin Oncol, 131, 191-8.

Sun YB, Xu S (2013). Expression of KiSS1 and KiSS1R (GPR54) may be used as favorable prognostic markers for patients with non-small cell a cancer. Int J Oncol, 43, 521-30.

Tachibana M, Kinugasa S, Dhar DK, et al (1999). Prognostic factors in T1 and T2 squamous cell carcinoma of the thoracic esophagus. Arch Surg, 134, 50-54

Taucher S, Rudas M, Mader RM, et al (2003). Do we need HER$2 /$ neu testing for all patients with primary breast carcinoma? Cancer, 98, 2547-53.

Ulasov IV, Kaverina NV, Pytel P, et al (2012). Clinical significance of KiSS1 protein expression for brain invasion and metastasis. Cancer, 118, 2096-105.

Wang H, Jones J, Turner T, et al (2012). Clinical and biological significance of KiSS1 expression in prostate cancer. Am J Pathol, 180, 1170-8

Yao HL, Yang ZL, Li YG et al (2007). In situ hybridization study on the expression of KiSS1 and KAI-1 metastasis suppressor genes in gastric cancer. Zhonghua Wei Chang Wai Ke Za Zhi, 10, 274-7 